\title{
Identifying Innovation Leverage in the University of Indonesia
}

\author{
Parulian Hutapea ${ }^{1}$, Martani Huseini ${ }^{2}$, Retno Kusumastuti ${ }^{2}$ \\ ${ }^{1}$ Bina Nusantara University, Address: Jl. Kyai H. Syahdan No 9, Kemanggisan, Kec. Palmerah, Kota Jakarta \\ Barat, DKI Jakarta 11480, Indonesia \\ ${ }^{2}$ University of Indonesia, Kampus Baru UI Depok Jawa Barat - 16424, Indonesia
}

\begin{abstract}
Indonesia has been looking for a way to improve its current policy applied for higher education institutions, which puts more weight on increasing publications in order to be able to survive in the future. They need to change their practices and behaviors in order to prepare for these future scenarios. One way to do it is by studying directly about the practices done at universities which become sources of innovation. This study is aimed at identifying the sources of innovation variables that have the highest leverage on research social innovation production. The study used a postpositivism paradigm by collecting 117 questionnaires and interviewing 24 informants from the University of Indonesia (UI). A system dynamic was used for simulation through Vensin PLE. The highest leverage to increase the number of publications, but not the patents and social innovations, came from a production loop consisting of UI research grants and rewards. However, the research rewards and grants cannot improve creativity and the innovation ecosystem. The University reward structure which put more weight on research publication output and ignore innovation ecosystem degrades the production of patent, social innovation as well as the teaching quality. Therefore, to set the priority of research publicity in the university the management of the university should not ignore the teaching and innovation practices.
\end{abstract}

DOI: $10.18421 /$ SAR31-06

https://doi.org/10.18421/SAR31-06

Corresponding author: Parulian Hutapea,

Bina Nusantara University, Address: Jl. Kyai H. Syahdan No 9, Kemanggisan, Kec. Palmerah, Kota Jakarta Barat, DKI Jakarta 11480, Indonesia.

Email: parulian2010@yahoo.com

Received: 27 January 2020.

Revised: 12 March 2020.

Accepted: 20 March 2020.

Published: 30 March 2020.

(cc) BY-NC-ND 2020 Parulian Hutapea, Martani Huseini \& Retno Kusumastuti; published by UIKTEN. This work is licensed under the Creative Commons AttributionNonCommercial-NoDerivs 3.0 License.

The article is published with Open Access at www.sarjournal.com
Keywords - higher education, innovation, ecosystem, system dynamics.

\section{Introduction}

Since 2015, many countries, especially Asian countries, have been competing to publish their research in highly ranked international journals to improve their positions in research [1]. This is because published research is mostly used as an indicator to get high status for the scientific capability of a country. According to [2], in terms of the ability to produce research, theories, and citations, in 2017 Indonesia was at a low position, which was at number 8 in Asia. So far, the Indonesian government has spent a lot of money on research. Even though the President of the Republic of Indonesia has set the total research budget for all ministries in 2019 at 24.9 trillion rupiah [3], he was still disappointed with the results which did not reach his expectations. Therefore, currently the government is still looking for a way to improve the research performance by using multiple approaches. One of them is by improving the research innovation process at the higher education level, which is considered as the starting point, and the first source to produce research innovation [4].

One of the indicators used to measure higher education productivity, besides teaching and function management, is its ability to produce research innovation outputs and outcomes, such as new knowledge, products, prototypes, and so on. Those outputs and outcomes are presented in terms of number of publications (both local and international), patents, and property rights. The process of research innovation in a higher education institution (HEI) starts from the production of individual creativity which has passed through the screening and adjustment stages in an organization to produce an outcome which is applicable in the business world and society [5]. A researcher who works within a highly regulated organizational environment should follow the organization's policies, rules, and regulations, as well as team up with other researchers to produce research innovations. So, in this context, 
there are three sources that should contribute to the production of research innovations:

- Individual creativity ([5], [6], [7]).

- Inovation ecosystem ([8], [9], [10]).

- Reward ([11], [12], [13], [14]).

Therefore, in order to able to manage the research outcomes and improve the social innovation production, universities should know which sources bring the highest leverage on the outcomes which lead to social innovation, so that they can set the priorities for innovation policies.

\subsection{Research Objectives}

- To identify the sources of innovation that produces the highest leverage on research social innovation production.

- To recognize what variables contribute to the sources of innovation which give the highest leverage.

Because a research production process is a part of an integrated process within the HEI's organization, and then, the use of system dynamics to analyze interaction between variables is very effective.

\section{Theoretical Framework}

\subsection{Innovation Process and Theories}

The term 'innovation' comes from the Latin word novus which means 'new'. Most of the time, it is connected to a perspective to introduce something new in an organization [15], including: a new product or service [16], a new idea creation, the new application of an idea, and new behavior in the organization [17]. In higher education, innovation is considered as the main agenda to be sustained in the future. In Indonesia, higher education institutions (HEIs) have to fulfill their obligations to follow the principles of tridharma, which are the teaching or learning process, research, and community service [4]. Research innovation in this article will focus on the second and third areas. Currently, HEIs' research activities put more weight on producing research publications in international journals and less weight on the research outcomes that have impacts on and added value for society. However, according to [18], the efforts for increasing publications are not enough to make universities able to survive or be sustainable beyond 2025. Therefore, they need to refocus their research policies to facilitate social innovations and added value for society.

When analyzing the innovation process in higher education organizations, two major theories are applied, which are: the creativity theory and the innovation ecosystem theory. The creativity theory focuses on the individual ability to produce an idea as the main source of innovation, while the ecosystem theory deals with the environment that affects the individual emotional condition in producing an idea. The overall theories are integrated by a grand theory called an Integrated Innovation Ecosystem.

\subsection{Individual Creativity}

Innovation exists because an individual has creativity. In a psychological concept, individual creativity is influenced by individual thriving [19], mood [20], and mindset [21]. Meanwhile, [22], with her psychoanalytic creativity concept, argues that an individual can be creative if one is in a space of creativity where one is able to manage one's anxiety; it means that the creativity itself is influenced by internal fantasies and the outside mind which is related to external realities. An external reality itself is represented by the environment where the individual produces one's creativity. An environment which is created by the interactions between the actors in the organization builds a complex relationship called an innovation ecosystem. A literature study identified some variables which contribute to the rise of innovation: mood, mindset, thriving, and creativity. Mood is shaped by one's attitude, feelings, and emotions, while mindset is an intellectual foundation which determines the capacity for creation (Stefanovich, 2011). By having a different mindset, someone has his/her own inspiration and thinks differently from other people.

\subsection{Innovation Ecosystem}

Recently, the term and definition of an innovation ecosystem is not consistently provided by literature. Therefore, the use of an innovation ecosystem may produce a very fragmented theory of an innovation ecosystem [23], [24] tried to find a construct of an innovation ecosystem by conducting a literature study. They proposed a different understanding between an innovation ecosystem and a business ecosystem.

This article used individuals as creativity and innovation units, and a university, researchers, as well as the government as ecosystem units (Figure 1). It used living organisms to describe an innovation ecosystem as a part of the innovation process [25], by whom the university, the government, and researchers interact with each other to produce creativity and innovation. In the original concept of living organisms, the interactions among living organisms in an innovation ecosystem involve people, culture, and technology [26] and produce collaborative arrangements through which parties combine their offerings into a coherent solution [27]. 


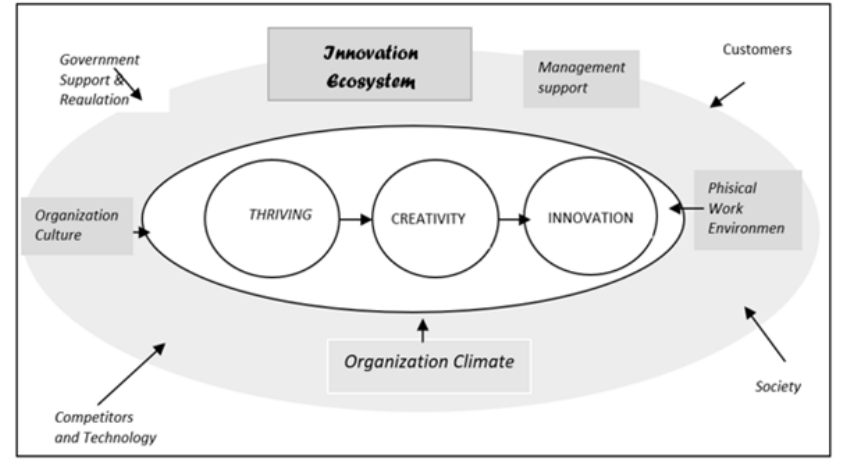

Figure 1. Innovation Ecosystem in HEI

Source: Constructed based on [28],[29],[30] and [11]

An organization is "a group of people who work interdependently toward some purpose" [31]. An organization can be considered as a part of the innovation ecosystem. People think, feel, and do things either individually or as a team in response to the rules, regulations, and policies imposed by the management in an organization. In an organization, the individual shares part of one's schema with other group members in terms by which one understands about the organizational climate and the organizational context [22].

In an innovation ecosystem context, the individual, team, organizational climate, culture, and organizational behavior can be considered as parts of the dynamic system, whose influences are represented by the variables forming the cause and effect relationships called an ecosystem loop. The current condition in the Asia Pacific region indicates that higher education institutions (HEIs) are expanding their capacity to accommodate the increasing number of students, while at the same time seeking to meet the high expectations for research and publications [32]. In this condition HEI's policy structure can create an equilibrium or determine a new direction to bring the energy of creativity.

\subsection{Motivation to Produce Research Innovations}

In the University of Indonesia, the output and the outcome of research innovations are measured by research publications in international journal publications, property rights, patents, and other social innovations. The university recognizes a research publication as an innovation output which is applicable for scientific purposes and a patent as an intellectual right granted by the state (Indonesia) to an inventor in technology, which has a strategic value to support national development and society welfare [33]. Meanwhile, social innovation is understood as the process of inventing, securing support for, and implementing novel solutions to social needs and problems [34]. The output of social innovation is used to support community service activities. Both patent and social innovations have the same goal which is to provide solutions and helps for society. The effort to get patents is bigger than to produce research publications, because the researcher must have publication and feasibility study both on the technical and commercial aspects to register the patent.

In the innovation systems thinking individual creativity, ecosystem and reward are related one to another. Once the thriving for creativity has been achieved within the innovation ecosystem, the universities need to give rewards, incentives, and research grants to increase work motivation to produce innovation outputs, innovation outcomes, and social innovations ([14], [35], [36], [37]). Therefore, establishing a reward policy may be able to change the norms and behaviors in the organization.

\section{Research Methodology}

\subsection{Research Design}

This research used a post-positivism approach, which assumes that the reality will not be fully understood and it can only be approached (Guba, 1990, in [38]). Therefore, post-positivism depends on multiple methods to capture a detailed description of reality (mixed method).

\subsection{Research Sample}

The questionnaires were distributed to 150 respondents in three faculty clusters (Health; Science and Technology; and Social Science), but only 117 respondents returned the completed questionnaires. The number of questionnaires collected is shown in table 1 below:

Table 1. Number of Questionnaires Collected

\begin{tabular}{|c|l|c|c|}
\hline No & \multicolumn{1}{|c|}{ Cluster } & $\begin{array}{c}\text { Number of } \\
\text { Questionnaires }\end{array}$ & Percentage \\
\hline 1. & Health & 51 & $43 \%$ \\
\hline 2. & $\begin{array}{l}\text { Science and } \\
\text { Technology }\end{array}$ & 30 & $26 \%$ \\
\hline 3. & Social & 36 & $31 \%$ \\
\hline \multicolumn{2}{|r|}{ Total } & 117 & $100 \%$ \\
\hline
\end{tabular}

Meanwhile, the qualitative data was captured by conducting interviews with 16 informants from the University of Indonesia and 9 informants from the Ministry of Research and Higher Education. 


\subsection{Research Instruments, Procedure and Testing}

This research used quantitative and qualitative data collections. The quantitative data collection utilized questionnaires, while the qualitative data collection used interviews. Quantitative historical data was used as actual information to be compared with the results forecasted by the dynamic model. The difference between the actual and forecast data indicates the error of the model.

Meanwhile, qualitative data was utilized to collect information to explain the phenomena that were not covered by the quantitative approach. Some of the information collected by the qualitative approach was applied to construct system thinking, and some other information was used for a qualitative analysis.

The research procedure is divided into several stages: the preliminary stage, the model construction stage, the data processing stage, model validation and simulation, and report writing (figure 2).

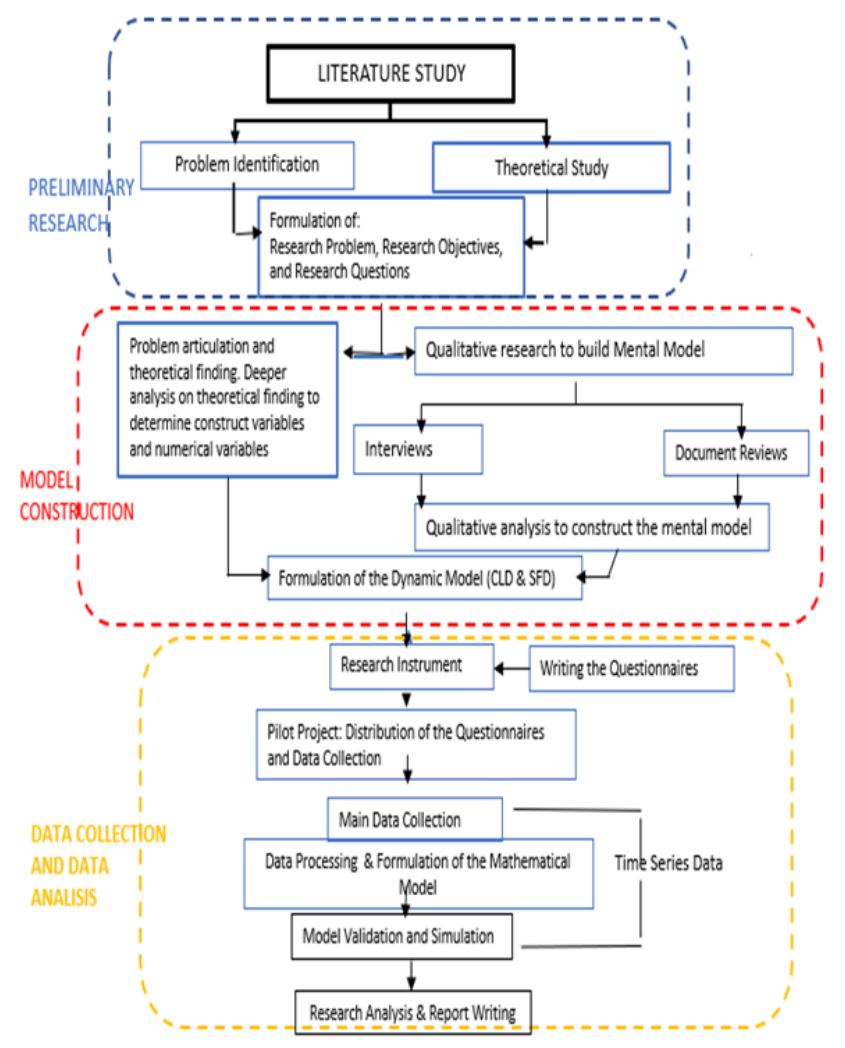

Figure 2. Research Process Flow Source: Constructed based on [39], [40].

\subsection{Data Analysis}

The validity and reliability of the questions used in the questionnaire were tested by using SPSS 15.0 (statistical package for Social Sciences) tests. They were all valid with $p$-values close to zero, and most of them had a Cronbach alpha of more than 6, which mean reliable. By applying a minimum MAPE of
$5 \%$ for all stock variables (table 2), they are all also valid because all stock variables have MAPE less than $5 \%$.

Table 2. Behavioral Validation Test Using Mean Absolute Percentage Error (MAPE) For the Stock Variables

\begin{tabular}{|c|c|c|c|c|c|c|}
\hline & 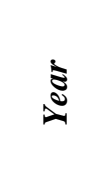 & $\underset{\substack{\tilde{\Xi} \\
\mathfrak{\Xi}}}{\mathfrak{\Xi}}$ & $\begin{array}{l}\overline{\mathbf{S}} \\
\mathbf{U} \\
\mathbb{U}\end{array}$ & $\sum_{1=1}^{\delta}$ & 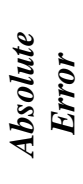 & 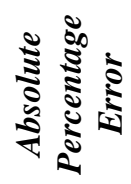 \\
\hline \multirow{6}{*}{ 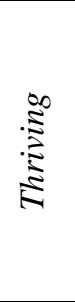 } & 2015 & 3.8 & 3.8 & 0 & 0 & $0 \%$ \\
\hline & 2016 & 3.8 & 3.8 & 0 & 0 & $0 \%$ \\
\hline & 2017 & 3.9 & 3.8 & 0.08 & 0.08 & $2 \%$ \\
\hline & 2018 & 3.9 & 3.9 & 0 & 0 & $0 \%$ \\
\hline & \multicolumn{5}{|l|}{ Total } & $2 \%$ \\
\hline & \multicolumn{5}{|c|}{ MAPE } & $1 \%$ \\
\hline \multirow{6}{*}{ 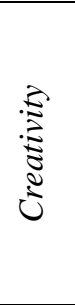 } & 2015 & 3.4 & 3.5 & -0.1 & 0.1 & $3 \%$ \\
\hline & 2016 & 3.5 & 3.5 & 0 & 0 & $0 \%$ \\
\hline & 2017 & 3.5 & 3.5 & 0 & 0 & $0 \%$ \\
\hline & 2018 & 3.6 & 3.6 & 0.04 & 0.04 & $1 \%$ \\
\hline & \multicolumn{5}{|l|}{ Total } & $4 \%$ \\
\hline & \multicolumn{5}{|c|}{ МАРE } & $1 \%$ \\
\hline \multirow{6}{*}{ 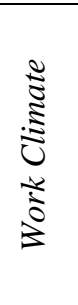 } & 2015 & 3.6 & 3.6 & 0 & 0 & $0 \%$ \\
\hline & 2016 & 3.6 & 3.6 & 0 & 0 & $0 \%$ \\
\hline & 2017 & 3.6 & 3.6 & 0 & 0 & $0 \%$ \\
\hline & 2018 & 3.6 & 3.6 & 0 & 0 & $0 \%$ \\
\hline & \multicolumn{5}{|l|}{ Total } & $0 \%$ \\
\hline & \multicolumn{5}{|c|}{ MAPE } & $0 \%$ \\
\hline \multirow{6}{*}{ 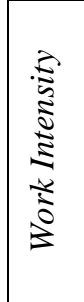 } & 2015 & 3.5 & 3.5 & 0.00 & 0.00 & $0 \%$ \\
\hline & 2016 & 3.5 & 3.5 & 0.02 & 0.02 & $1 \%$ \\
\hline & 2017 & 3.6 & 3.5 & 0.05 & 0.05 & $1 \%$ \\
\hline & 2018 & 3.6 & 3.5 & 0.06 & 0.06 & $2 \%$ \\
\hline & \multicolumn{5}{|l|}{ Total } & $4 \%$ \\
\hline & \multicolumn{5}{|c|}{ MAPE } & $1 \%$ \\
\hline \multirow{6}{*}{ 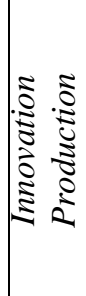 } & 2015 & 1196 & 1196 & 0 & 0 & $0 \%$ \\
\hline & 2016 & 1515 & 1538 & -23 & 23 & $2 \%$ \\
\hline & 2017 & 2724 & 2781 & -57 & 57 & $2 \%$ \\
\hline & 2018 & 3445 & 3117 & 328 & 328 & $11 \%$ \\
\hline & \multicolumn{5}{|l|}{ Total } & $14 \%$ \\
\hline & \multicolumn{5}{|c|}{ МАРЕ } & $5 \%$ \\
\hline
\end{tabular}

Source: Summarized based on SPSS output, 2020

\section{Results and Discussion}

\subsection{Relationship between Ecosystem Variables and Research Leverage Drivers}

leverage drivers (thriving and creativity) in the thrbnee clusters in The University of Indonesia. 
Table 3. The Relationship between Ecosystems Variables and Research Leverage Drivers Variables in Science and Technology, Health, and Social Science Clusters

\begin{tabular}{|c|c|c|c|c|}
\hline \multirow[b]{2}{*}{ No } & \multirow[b]{2}{*}{ Variable } & \multicolumn{3}{|c|}{ Average Scores in 2015-2018 } \\
\hline & & 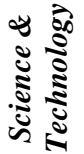 & \begin{tabular}{l}
$\mathbf{\Xi}$ \\
\multirow{\Xi}{\Xi}{}
\end{tabular} & 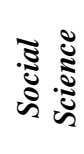 \\
\hline & \multicolumn{4}{|c|}{ Ecosystems Variables: } \\
\hline 1. & Teamwork & 4.00 & 3.83 & 3.40 \\
\hline 2. & $\begin{array}{l}\text { Work } \\
\text { Climate }\end{array}$ & 3.75 & 3.75 & 3.30 \\
\hline 3. & $\begin{array}{l}\text { Work } \\
\text { Culture }\end{array}$ & 3.98 & 3.90 & 3.50 \\
\hline \multirow[t]{3}{*}{4.} & $\begin{array}{l}\text { Positive } \\
\text { Mood }\end{array}$ & 3.95 & 3.83 & 3.57 \\
\hline & Average & 3.92 & 3.83 & 3.44 \\
\hline & \multicolumn{4}{|c|}{ Research Leverage Drivers: } \\
\hline 1. & Thriving & 4.13 & 3.93 & 3.45 \\
\hline 2. & Creativity & 3.90 & 3.65 & 2.95 \\
\hline & Average & 4.02 & 3.79 & 3.20 \\
\hline
\end{tabular}

Source: Processed by the researcher from the questionnaires, 2020

The higher the ecosystem variable scores were, the better the research leverage driver produced. For example, the Science and Technology cluster, which has a high ecosystem score (3.92), produced an innovation result of 4.02. Meanwhile, the Social Science cluster, which has a lower ecosystem score (3.44), produced a lower innovation result (3.20). There are some reasons why the Science and Technology and Health and Medical clusters have higher scores in the ecosystem variables than the Social Science cluster:

- Naturally, the work process in the Technical and Engineering as well as the Science and Medical clusters requires teamwork of people who have different skills. Besides that, they are accustomed to work in a team when doing their activities. A faculty research manager in the Engineering Department said:

- "We are working here as a team ... normally to do everything we talk about it first and get an agreement together. They ask if everyone agrees about it or not. If they need some changes, to add or reduce something, it's okay. They fix it together."

- The management in the Technical and Engineering clusters apply a team management practice. The research manager of the Engineering cluster said:

- "We work here using team management which is initiated by the department head." Team management is also applied for distributing the research target or budget. As mentioned by the research manager: "We do the balancing for each researcher ... for their budget and their target. Once it is decided by the department head, the researchers usually accept it."

- The work culture and in-group ownership in the Health cluster are very strong. People are proud to see their institution's success and they are willing to grow and develop their university together. As expressed by a Health department head: "We are working here ... we want to be successful and we are proud of UI ... that is our mindset."

- There is a clear differentiation of the skills or competences in the Engineering, Science and Medical clusters. Meanwhile, in the Social Science cluster, the border between skills and competences is sometimes not clearly identified. Therefore in the Engineering, Science and Medical clusters the researchers do not compete in the same area of skills and competences, but in the social science cluster the researchers are possibly compete in the same area of skills and competences.

\subsection{System dynamic Stock Flow Diagram (SFD) of the Research Innovation}

Figure 3 describes a stock flow diagram (SFD) of the research innovation process at the University of Indonesia. There are three types of variables involved in the diagram: the stock variable, the flow variable, and the regular variable. The stock variables are presented with 5 boxes: work intensity, work climate, thriving, creativity and research innovation production; the flow variables are presented with 5 double line arrows and the regular variables are consisting of: work intensity inflow, thriving inflow, creativity inflow, work climate rate, productivity and the other variables. All of those variables construct the stock flow diagram of the research innovation production in the University of Indonesia.

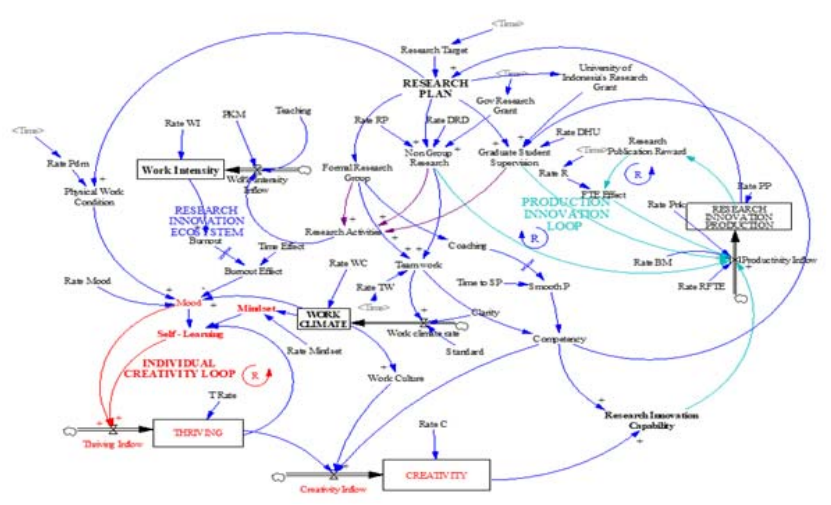

Figure 3. Stock Flow Diagram (SFD) of the Research Innovation Production at the University of Indonesia Sources: Constructed by the researcher using data from a literature study and interviews, processed by Vensim PLE x32. 
By running a system dynamic simulation using the mathematical formula in the stock flow diagram in figure 3, it produces the result described in the table 4. Tabel 4 shows the simulation effects of the $10 \%$ increase of the research loop variables (individual creativity loop, research ecosystem loop and research production loop variables) on the innovation result variables (thriving, creativity and production variables).

Table 4. The effect of a $10 \%$ increase of the Individual Creativity, Research Ecosystem, and Production Loop Variables on the innovation result variables (thriving, creativity, and production)

\begin{tabular}{|c|c|c|c|c|c|}
\hline Variables & 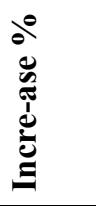 & 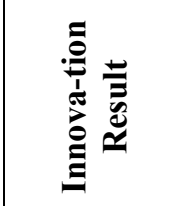 & 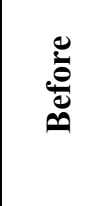 & $\stackrel{\bar{\Xi}}{\varrho}$ & 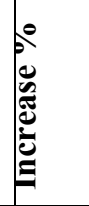 \\
\hline \multicolumn{6}{|c|}{ 1. Individual Creativity Loop } \\
\hline Mindset & $10 \%$ & Thriving & 3.92 & 3.93 & 3.0 \\
\hline \multirow[t]{3}{*}{ Mood } & $10 \%$ & Creativity & 3.56 & 3.62 & 1.5 \\
\hline & & Sub total & & & 0.9 \\
\hline & & Production & 3445 & $\begin{array}{c}368 \\
8\end{array}$ & 7.1 \\
\hline \multicolumn{6}{|c|}{ 2. Research Ecosystem } \\
\hline Team-work & $10 \%$ & Thriving & 3.92 & 3.92 & 0.0 \\
\hline $\begin{array}{l}\text { Physical Work } \\
\text { Condition }\end{array}$ & $10 \%$ & Creativity & 3.56 & 3.62 & 1.5 \\
\hline Standard & $10 \%$ & Sub total & & & 0.7 \\
\hline Clarity & $10 \%$ & Production & 3445 & 3688 & 7.1 \\
\hline Work Climate & $10 \%$ & & & & \\
\hline $\begin{array}{l}\text { Work } \\
\text { Intensity }\end{array}$ & $10 \%$ & & & & \\
\hline \multicolumn{6}{|c|}{ 3. Research Production Loop } \\
\hline \begin{tabular}{l|} 
Publication \\
Reward
\end{tabular} & $10 \%$ & Thriving & 3.92 & 3.92 & 0.0 \\
\hline $\begin{array}{l}\text { Government } \\
\text { Grant }\end{array}$ & $10 \%$ & Creativity & 3.56 & 3.63 & 1.8 \\
\hline $\begin{array}{l}\text { Univ of } \\
\text { Indonesia Grant }\end{array}$ & $10 \%$ & Total & & & 0.9 \\
\hline \begin{tabular}{l|} 
Graduate \\
Student \\
Supervision \\
\end{tabular} & $10 \%$ & Production & 3445 & 4089 & 19 \\
\hline Compe-tency & $10 \%$ & & & & \\
\hline
\end{tabular}

Source: Prepared by the researcher from simulation outputs using Vensim PLE, 2020

The table 4 shows that the research production loop has the highest leverage because by increasing the production loop variables by $10 \%$, it causes a $19 \%$ increase in production. In contrast, the individual creativity loop and the research ecosystem innovation loop only cause a production increase of $7.1 \%$ each. That means the University of Indonesia failed to improve the highest individual creativity of its researchers and the organization's innovation ecosystem. In this university, the research innovation production was measured by the total published Scopus papers, patents submitted, patents granted, and property rights which were measured based on the credit equivalent (Table 5). Meanwhile, the exact data for social innovation was not available, but based on an unrecorded interview with a senior researcher it is very small and insignificant. The table indicates that the total innovation production increased in 2017 and 2018 by only the number of publications and property rights. However, the patent production in this period was zero. If it is related to the data in table 4 , it shows that the total creativity increases produced by all loops were low $(1.5 \%$ and $1.8 \%)$. Meanwhile, the total innovation productions were high $(7.1 \%$ and $19 \%)$. This means that the university does not produce high creativity, but only has high research publication production. So, the grants and rewards given to the researchers can only motivate the researchers to increase their publication research but not creativity.

Table 5. Total Production (Measured Based on the Credit Equivalent) from 2015-2018

\begin{tabular}{|l|c|c|c|c|}
\hline & $\mathbf{2 0 1 5}$ & $\mathbf{2 0 1 6}$ & $\mathbf{2 0 1 7}$ & $\mathbf{2 0 1 8}$ \\
\hline Scopus publication & 729 & 1109 & 2440 & 3413 \\
\hline $\begin{array}{l}\text { Scopus } \\
\text { (Credit Equivalent) }\end{array}$ & 1137 & 1481 & 2757 & 3060 \\
\hline Property Rights & 61 & 128 & 236 & 566 \\
\hline $\begin{array}{l}\text { Property Rights } \\
\text { (Credit Equivalent) }\end{array}$ & 6 & 13 & 24 & 57 \\
\hline Patents Submitted & 35 & 49 & 0 & 0 \\
\hline Patents Granted & 9 & 5 & 0 & 0 \\
\hline $\begin{array}{l}\text { Total Patents } \\
\text { (Credit Equivalent) }\end{array}$ & 53.5 & 44.5 & 0 & 0 \\
\hline $\begin{array}{l}\text { Total Production } \\
\text { (Credit Equivalent) }\end{array}$ & 1196 & 1538 & 2781 & 3117 \\
\hline
\end{tabular}

If this result is crosschecked with the data of fund allocations in 2018, which had a higher portion for publication rewards and grants than for patents and social innovations (161.925 billion rupiah for research publications and 16.4 billion rupiah for patents and social innovations), then it can be concluded that the research rewards and grants only leverage the number of publications, but does not improve creativity. This is in line with a senior researcher who expressed his dissatisfaction as in the following:

“... most people (meaning lecturers) only spend most of their time to target the Scopus journal publications, for example like me ... most of the time I only have a little time for teaching preparation ... no time for thinking about creativity to produce 
anything for society at all ... It's the university's policy."

The result of sensitivity test of the research production loop variables in the table 6 shows that the University of Indonesia research grant and student supervision variables give the highest contributions to research innovation production, because by increasing each of these variables (UI grants and student supervision) by $10 \%$ while keeping the other variables the same, it causes a $15 \%$ increase in research production. In comparison, the publication reward $10 \%$ increase is only able to increase research production by $10.3 \%$, while the government research grant and competency are only able to increase $7 \%$ of the research production. This concludes that the leverage of the publication productivity comes from the graduate students, not solely from the lecturers.

Table 6. Sensitivity of the Research Production Loop Variables

\begin{tabular}{|c|c|c|c|c|c|}
\hline 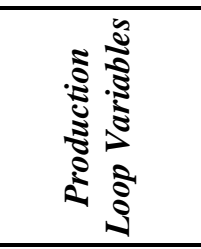 & 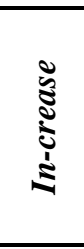 & 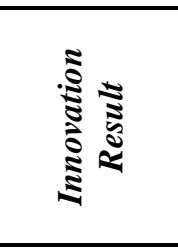 & $\frac{0}{2}$ & $\sum_{\bar{\pi}}^{\bar{z}}$ & $\begin{array}{l}d 0 \\
\vdots \\
\vdots \\
\vdots \\
\vdots \\
\vdots \\
\vdots\end{array}$ \\
\hline \multirow[t]{4}{*}{$\begin{array}{l}\text { Publication } \\
\text { Re-wards }\end{array}$} & $10 \%$ & Thriving & 3.92 & 3.92 & 0.0 \\
\hline & & Creativity & 3.56 & 3.56 & 0.0 \\
\hline & & Total & & & 0.0 \\
\hline & & Production & 3445 & 3800 & 10.3 \\
\hline \multirow[t]{4}{*}{$\begin{array}{l}\text { Government } \\
\text { Grants }\end{array}$} & $10 \%$ & Thriving & 3.92 & 3.92 & 0.0 \\
\hline & & Creativity & 3.56 & 3.56 & 0.0 \\
\hline & & Total & & & 0.0 \\
\hline & & Production & 3445 & 3694 & 7.0 \\
\hline \multirow[t]{4}{*}{ UI Grants } & $10 \%$ & Thriving & 3.92 & 3.92 & 0.0 \\
\hline & & Creativity & 3.56 & 3.56 & 0.0 \\
\hline & & Total & & & 0,0 \\
\hline & & Production & 3445 & 3964 & 15.0 \\
\hline \multirow[t]{4}{*}{$\begin{array}{l}\text { Stu-dent } \\
\text { Super- } \\
\text { vision }\end{array}$} & $10 \%$ & Thriving & 3.92 & 3.92 & 0,0 \\
\hline & & Creativity & 3.56 & 3.56 & 0.0 \\
\hline & & Total & & & 0.0 \\
\hline & & Production & 3445 & 3965 & 15.0 \\
\hline \multirow[t]{4}{*}{ Competency } & $10 \%$ & Thriving & 3.92 & 3.92 & 0.0 \\
\hline & & Creativity & 3.56 & 3.56 & 0.1 \\
\hline & & Total & & & 0,1 \\
\hline & & Production & 3445 & 3688 & 7.0 \\
\hline
\end{tabular}

Source: Prepared by the researcher from simulation output using Vensim PLE, 2020.

\section{Conclusion}

\subsection{Conclusion}

- The highest leverage to increase the number of publications, excluding patents and social innovations, came from a production loop consisting of UI research grants and rewards. However, the system dynamic simulation attested that the research grants and rewards, which have the highest leverage to produce research publications, cannot improve the creativity and the social innovation. This supports the reward and motivation micro theory proposed by [41] and [42] that claims the reward does not increase the capacity to innovate.

- The university policy that puts more weight on research publication production reduces the time for improving teaching quality and producing patent and social innovation.

- The time constraints and unsupported innovation ecosystem hinder the achievement of patent or social innovation. The time constraints and unsupported innovation ecosystem hinder the achievement of patent or social innovation.

\subsection{Implication for Research and Practice}

The University reward structure which put more weight on research output and ignore innovation ecosystem degrades the production of patent, social innovation as well as the teaching quality. Therefore, to set the priority of research publicity in the university should not ignore the teaching and innovation practices.

\subsection{Recommendations}

To improve social research performance the University of Indonesia should not focus only on the research publication improvement, but also has to consider social research innovation such as patent and social innovation which bring impact on the society as well as teaching quality improvement which contribute to the business of the University of Indonesia.

\subsection{Suggestions for Future Research}

System dynamic is a closed system approach which is effective to analyze the dynamic interaction between variables in the organization, but to bring more impact of the research on the society the future scope of the research should be enlarged to a national size. 


\section{References}

[1]. Tai, P. (2015). Why the Asian craze for publication?: An examination from academic regime. Research, development, and innovation in Asia Pacific higher education, 61-79.

[2]. Scimago Journal and Country Rank (2018). Retrieved from:

https://www.scimagojr.com/countryrank.php?region= Asiatic\%20Region\&year=2018. [accessed: 14. January 2019].

[3]. Detikfinance (2018). Singgung Anggaran Penelitian Rp 24 T, Jokowi: Apa Hasilnya?. Retrieved from: https://finance.detik.com/berita-ekonomi-bisnis/d3961968/singgung-anggaran-penelitian-rp-24-tjokowi-apa-hasilnya. [accessed: 24 December 2020].

[4]. Law of the Republic of Indonesia No. 122012 on Higher Education. Retrieved from: https://wiki.creativecommons.org/images/f/f4/Indones ia Higher_Ed Law (2012).pdf. [accessed: 01. December 2019].

[5]. Anderson, N., De Drew, C. K. W., \& Nijstad, B. A. (2004). The routinization of innovation research: A constructively critical review of the state of the science. Journal of Organizational Behaviour, 25(2), 147-173.

[6]. Scott, S. G., \& Bruce, R. A. (1994). Determinants of innovative behavior: A path model of individual innovation in the workplace. Academy of Management Journal, 37(3), 580-607.

[7]. Simonton, D. K. (1988b). Creativity, leadership, and chance. In $R$. J. Sternberg (Ed.), The nature of creativity: Contemporary psychological perspectives, 386-426.

[8]. Yoshida, D. T., Sendjaya, S., Hirst, G., \& Cooper, B. (2014). Does servant leadership foster creativity and innovation? A multi-level mediation study of identification and prototypicality. Journal of Business Research, 67(7), 1395-1404

[9]. Spreitzer, G., Sutcliffe, K., Dutton, J., Sonenshein, S., and Grant, A.M. (2005). A socially embedded model of thriving at work. Organization Science, 16(5), 537-549.

[10]. Amabile, T. M. (1997). Motivating creativity in organisations: On doing what you love and loving what you do. California Management Review, 40(1), 39-59.

[11]. Wallace, J.C., Butt, M.M., Johnson, P.D, Stevens, F.G., \& Smith, M. B. (2016). A Multilevel model of employee innovation: Understanding the effects of regulatory focus, thriving, and employee involvement climate. Journal of Management, 42(4), 982-100.

[12]. Rosenblatt, M. (2011). The use of innovation awards in the public sector: Individual and organizational perspectives. Innovation: Management, Policy, and Practice, 13(2), 207-219

[13]. Marx, R., Soares, J. P. R. F., \& Barros, L. S. (2016). Organizational context variables to be considered in the reward system design oriented to product innovation. Review of Business Management, 18(60), 267-289.
[14]. Hsiao, H., Chang, J., \& Chen (2013). The Influence of support for innovation on Organizations. AsiaPacific Edu Res, 23(3), 463-472.

[15]. Sarros, J. C., Cooper, B. K., \& Santora, J. C. (2008). Building a climate for innovation through transformational leadership and organizational culture. Journal of Leadership \& Organizational Studies, 15(2), 145-158.

[16]. Thompson, J. D. (1967). Organizations in action. McGraw Hill.

[17]. Daft, R. L. (1978). A dual-core model of organizational innovation. The Academy of Management Journal, 21(2), 193-210.

[18]. Blass, E. \& Hayward, P. (2014) Innovation in higher education: Will there be a role for "The Academy/University" in 2025? European Journal of Futures Research, 41(2), 1-9.

[19]. Nix, G. A., Ryan, R. M., Manly, J. B., \& Deci, E. L. (1999). Revitalization through self-regulation: The effect of autonomous and controlled motivation on happiness and vitality. Journal of Experimental Social Psychology, 35, 266-284.

[20]. Stefanovich, A. (2011). Look at more: A proven approach to innovation, growth, and change. JosseyBass.

[21]. Dweck, C. (2006). Mindset: The new psychology of success. Random House.

[22]. Stacey, R. D. (2003). Strategic management and organisational dynamics: The challenge of complexity. Prentice Hall.

[23]. Oh, D. S., Phillips, F., Park, S., \& Lee, E. (2016). Innovation ecosystems: A critical examination. Technovation, 54, 1-6.

[24]. Gomes, L. A. V., Facin, A. L. F., Salerno, M. S., \& Ikenami, R. K. (2018). Unpacking the innovation ecosystem construct: Evolution, gaps and trends. Technological Forecasting Social Change, 136, 3048.

[25]. Valkokari, K. (2015). Business innovation and knowledge ecosystems: How they differ and how to survive and thrive within them. Technology Innovation Management Review, 8(5), 17-24.

[26]. Carayannis, E. G., \& Campbell, D. F. J. (2009). 'Mode 3' and 'Quadruple Helix': Toward a 21st century fractal innovation ecosystem. International Journal Technology Management, 46(3/4), 201-234.

[27]. Adner, R. (2006). Match your innovation strategy to your innovation ecosystem. Harvard Business Review.

[28]. Albers, J. A., \& Brewer, S. (2003). Knowledge management and the innovation process: the ecoinnovation model. Journal of Knowledge Management Practice, 4(6), 1-6.

[29]. Trias De Bes, F., \& Kotler, P. (2015). Winning at innovation. The A-to-F Model. Palgrave Macmillan.

[30]. Wang, W., \& Wang, Y. (2016). Integrated Innovation Theory: Theory Exploration of a Complex System. Management \& Engineering, (23), 228.

[31]. McShane, S.L. \& Glinow, V. (2015). Organizational behaviour. Emerging knowledge, global reality. McGraw Hill. 
[32]. Hawkins, J. N. (2015). The shifting ecology of research in Asian Pacific Higher Education Imitation or Innovation. Research, development, and innovation in Asia pacific higher education, 31-49.

[33]. Official State Buletin Republic of Indonesia. (2018). Regulation of Minister of Law and Human Rights of Republic Indonesia no 15 year 2018 on implementation of patent by patent holder. Retrieved from: http://ambadar.co.id/site/wpcontent/uploads/2018/11/Regulation-No-15-of2018.pdf [accessed: 21. December 2019].

[34]. Phills Jr, J.A., Deiglmeier, K. and Miller, D.T. (2008). Rediscovering social innovation. Stanford Social Innovation Review.

[35]. Baumann, O., \& Stieglitz, N. (2014). Rewarding value-creating ideas in organizations: The power of low-powered incentives. Strategic management journal, 35(3), 358-375.

[36]. Barczak, G., Griffin A., \& Kahn, K. B. (2009). Perspective: Trends and drivers of success in NPD practices: Results of the 2003 PDMA best practices study. Journal of product innovation management, 26(1), 3-23.
[37]. Jiang, J., Wang, S., \& Zhao, S. (2012). Does HRM facilitate employee creativity and organizational innovation? A study of Chinese firms. International journal of human resource management, 23(19), 4025-4047.

[38]. Denzin, N. K., \& Lincoln, Y. S. (2000). The discipline and practice of qualitative research. Handbook of Qualitative Research, SAGE.

[39]. Maani, E. K., \& Cavana, Y. R. (2000). Systems thinking modelling. Pearson Education.

[40]. Sterman, J. D. (2000). Business dynamics systems thinking and modeling for a complex world. The McGraw-Hill Company.

[41]. Amabile, T. (1988). A model of creativity and innovation in organizations. In B. M. Staw's Research in Organizational Behavior, 10, 123-167.

[42]. Burroughs, J. E., Dahl, D. W., Moreau, C. P., Chattopadhyay, A., \& Gorn, G. J. (2011). Facilitating and rewarding creativity during new product development. Journal of marketing, 75(4), 53-67. 